\title{
The use of spectral natural gamma-ray analysis in reservoir evaluation of siliciclastic sediments: a case study from the Middle Jurassic of the Harald Field, Danish Central Graben
}

\author{
Ida L. Fabricius, Louise Dahlerup Fazladic, Armgard Steinholm and Uffe Korsbech
}

A cored sandstone interval from the Middle Jurassic Harald Field of the Danish North Sea was chosen for an investigation of the mineralogical sources for the gamma-ray activity, and with the purpose of determining how the Spectral Natural Gamma (SNG) log could be used as an indicator of reservoir quality. Core intervals of quartz arenites and quartz wackes were selected.

Although no linear relationship was found between clay content and potassium (K), thorium (Th), or uranium (U), the K content characterises three discrete lithofacies. Lithofacies I has a grain-supported texture, with a predominance of quartz grains; only minor fine-grained matrix is present. Sandstones of lithofacies I have a low $\mathrm{K}$ content and most of the $\mathrm{K}$ is hosted in feldspar. Porosity varies between $23 \%$ and $28 \%$ and permeability is in the range $200-2000 \mathrm{mD}$. Lithofacies II sandstones have a grain-supported texture, with a predominance of quartz grains; fine-grained matrix fills the intergranular volume. Sandstones of lithofacies II have an intermediate $\mathrm{K}$ content, with K-feldspar, mica, and illite as the main sources. Porosity varies between $11 \%$ and $17 \%$ and permeability is in the range $0.4-25 \mathrm{mD}$. Lithofacies III has a matrix-supported texture with quartz grains floating in a clay-rich matrix. Samples from lithofacies III have the highest K signal. Illite and illitised kaolinite are roughly equal in importance as sources of K. Porosity is up to $11 \%$ and permeability up to $0.5 \mathrm{mD}$. The Th and $\mathrm{U}$ content of all lithofacies is governed primarily by the presence of heavy minerals; no apparent general relationship between $\mathrm{U}$ and Total Organic Carbon (TOC) was found.

Comparisons between the core measurements of $\mathrm{K}$, Th, and $\mathrm{U}$, and the SNG log disclosed a discrepancy between the calibrations of laboratory and borehole measurements. For U the discrepancy contains an erratic element, whereas the difference for $\mathrm{K}$ and $\mathrm{Th}$ can be eliminated by correction factors. Thus, the conclusions based on laboratory measurements appear to be applicable to the log data, and, using corrected $\mathrm{K}$ values, the facies subdivision can be extended throughout the reservoir section based on the SNG log.

Keywords: Danish Central Graben, North Sea, Middle Jurassic, sandstone reservoir, gamma-ray spectometry, mineralogy, geochemistry

I.L.F., L.D.F.*, A.S. \& U.K., Technical University of Denmark (DTU), DK-2800 Lyngby, Denmark. *Present address: Internationalt Patent-Bureau, DK-2630 Tåstrup, Denmark. `Present address: Jarðfrøðisavnið, Brekkutún 1, FO-110 Tórshavn, Faroe Islands. E-mail: ilf@er.dtu.dk 
Natural gamma-ray wireline logging is commonly used for lithological, or more precisely mineral, identification in boreholes. In sandstone reservoir sections, its main purpose is to obtain an indication of the clay content and thus, reservoir quality. Schlumberger (1982) has described two types of gamma-ray logs: the conventional Gamma Ray log records the total natural gamma radiation in the borehole independent of the energy of the gamma rays, whereas the Spectral Natural Gamma-ray (SNG) probe measures the gamma-ray spectrum, i.e. the energy distribution of the gamma rays. The gamma rays originate from the decay of radiogenic potassium $\left({ }^{40} \mathrm{~K}\right)$, thorium $\left({ }^{232} \mathrm{Th}\right)$ and uranium $\left({ }^{238} \mathrm{U}\right)$, each of which exhibit a characteristic energy spectrum. The measured energy spectrum is transformed into concentrations of K, Th and U (Schlumberger 1982).

In the West Lulu-3 appraisal well of the Middle Jurassic Harald Field, SNG logging was performed in order to differentiate micaceous sand from shale. This distinction should in theory be possible from the $\mathrm{Th} / \mathrm{K}$ ratio, but the picture is complicated because several radioactive minerals are present in the micaceous sandstones that give a more shale-like response. The purpose of this study was to identify the radioactive minerals in the sandstones and to estimate their contribution to the gamma-ray spectrum. Furthermore, the aim was to identify the gamma-spectral characteristics of intervals with different reservoir quality. With these objectives, we sampled the cores of West Lulu-3 and defined three lithofacies based on petrographical and mineralogical data. The three lithofacies chosen are expected to have characteristic reservoir qualities as reflected by porosity and permeability. Gamma-spectral data were obtained in the laboratory for each of the three lithofacies, and the laboratory data were compared with the log data.

\section{The Harald Field}

The Harald Field is situated in the Danish portion of the Søgne Basin in the north-eastern part of the Danish Central Graben (Fig. 1). The hydrocarbon reservoir is located in sandstones of the Middle Jurassic Bryne and Lulu Formations (Johannessen \& Andsbjerg 1993; Andsbjerg 2003, this volume; Michelsen et al. 2003, this volume). According to Johannessen \& Andsbjerg (1993) and Andsbjerg (2003, this volume), this succession represents a range of paralic and coastal plain environments (Fig. 2), and is overlain by the marine shales of the Lola Formation. The SNG log over the cored section of West Lulu-3 is represented in Figure 3.

\section{Geochemistry of potassium, thorium and uranium}

Hassan et al. (1976) examined the mineralogy and chemical composition of 500 samples of varying lithology from different environments of deposition. Of particular relevance to this work, their data included $\mathrm{K}$, Th and $\mathrm{U}$ measurements. The following conclusions concerning the occurrence of these three elements are based on Hassan et al. (1976) as well as Schlumberger (1982), and Nielsen et al. (1987).

\section{Potassium}

Potassium is a major element in many rock-forming minerals. The radioactive isotope ${ }^{40} \mathrm{~K}$ constitutes $0.0118 \%$ of the total potassium in a mineral, and the gamma signal from the radioactive decay is an important indicator of mineralogical composition. The most common $\mathrm{K}$-bearing minerals in sedimentary rocks are K-feldspar, mica and illite. K-feldspar and mica are more common in sandstones, illite in shales. K-feldspar and mica have a greater $\mathrm{K}$ content than illite, and thus the gamma-ray flux is only a measure of clay content in the absence of significant K-feldspar (Cowan \& Myers 1988). Glauconite can also be a significant source of $\mathrm{K}$ in sedimentary rocks. Typical potassium contents of K-bearing minerals are: illite, 4.5\%; muscovite, 7.9-9.8\%; plagioclase, 0.54\%; K-feldspar, 10.9-14.0\% (Nielsen et al. 1987). Engstrøm (1981) measured K, Th and U in Danish Cenozoic strata (clay, silt and sand) and found results in accordance with the distributions and concentrations mentioned above. Kaolinite is sometimes reported to contain minor amounts of $\mathrm{K}$ and $\mathrm{Th}$, but ideal kaolinite contains neither elements (see below).

Straightforward relationships between K and clay content should not be expected. In Miocene-Pliocene shales from the North Sea, Berstad \& Dypvik (1982) found a positive correlation between $\mathrm{K}$ and the clay content. This was inferred to be mainly controlled by the illite of the clay fraction. On the contrary, in Paleocene and Eocene strata, radioactivity and clay content are negatively correlated. This is probably because the clay fraction is rich in a Kpoor smectite, derived from basaltic volcanic material.

\section{Thorium}

Thorium is a common trace element in most geological environments. In weathering environments it is prac- 


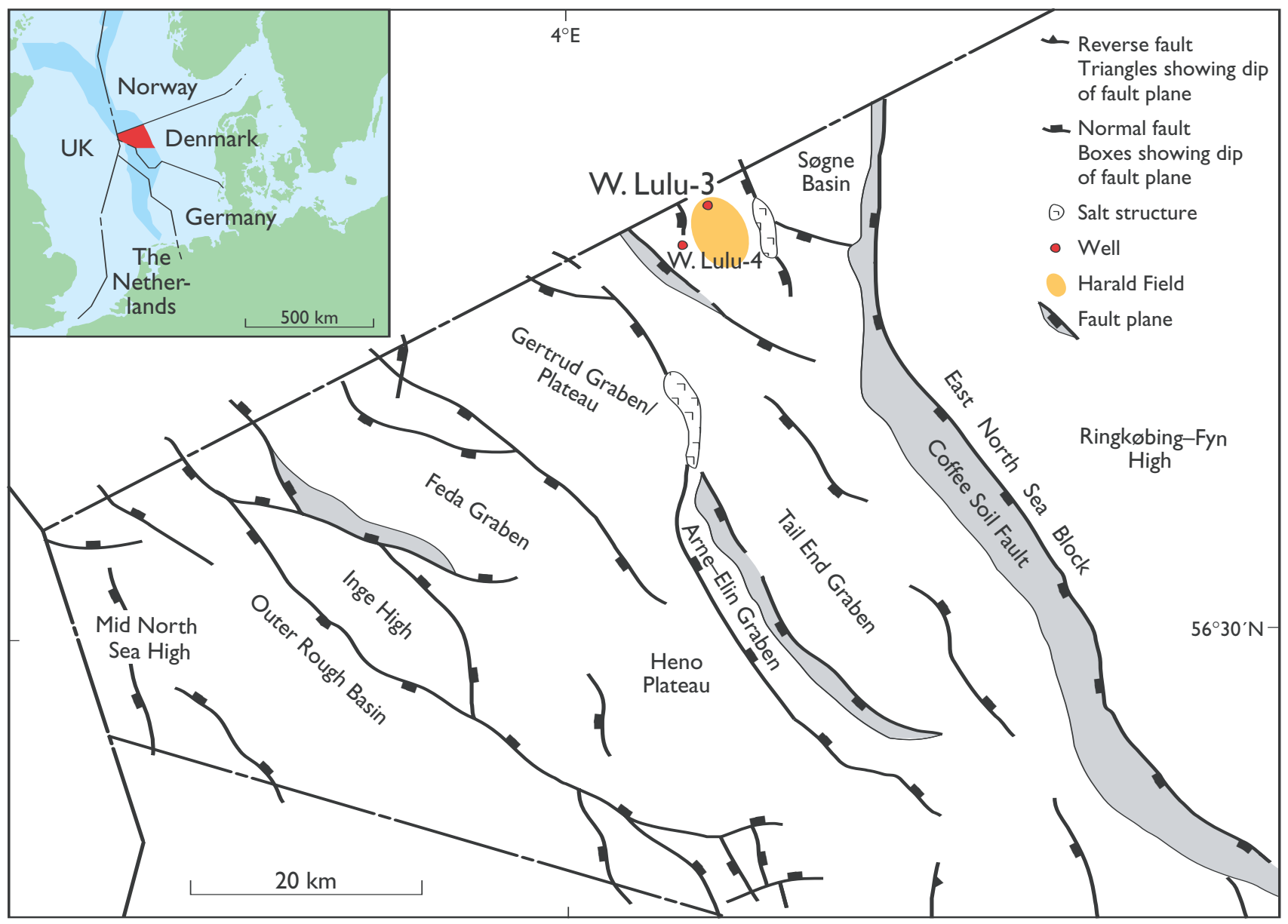

Fig. 1. The location of the West Lulu-3 well within the Harald Field in the Danish sector of the North Sea Central Graben. Inset map shows the Central Graben (blue) straddling the national boundaries and branching northwards into the Outer Moray Firth and Viking Graben systems; the area of the enlarged map of the northern Danish Central Graben is indicated in red

SSW

$$
\text { W. Lulu-4 Lulu-3 }
$$

NNE

Fig. 2. Log correlation of the Middle Jurassic in the Harald Field area showing the stratigraphic position of the West Lulu-3 cored section under study in this paper; for location of wells, see Fig. 1. Modified from Andsbjerg (2003, this volume)

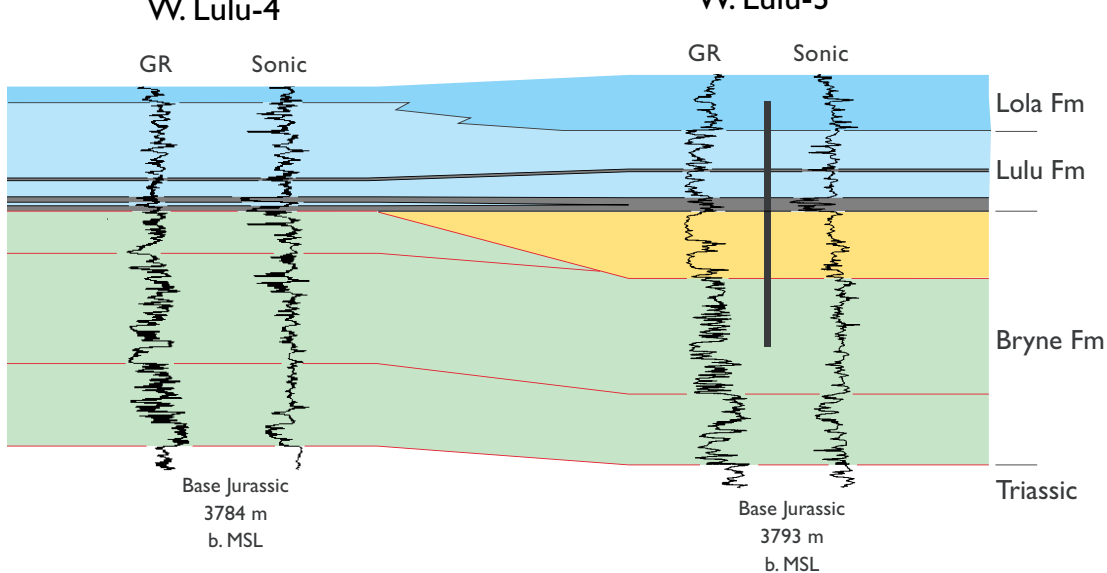

Shallow marine (mud-dominated)

Paralic and shallow marine (sand-dominated)

Fluvial and estuarine in incised valley

$50 \mathrm{~m}$

Sequence boundary

Studied core section

Alluvial plain and lacustrine 


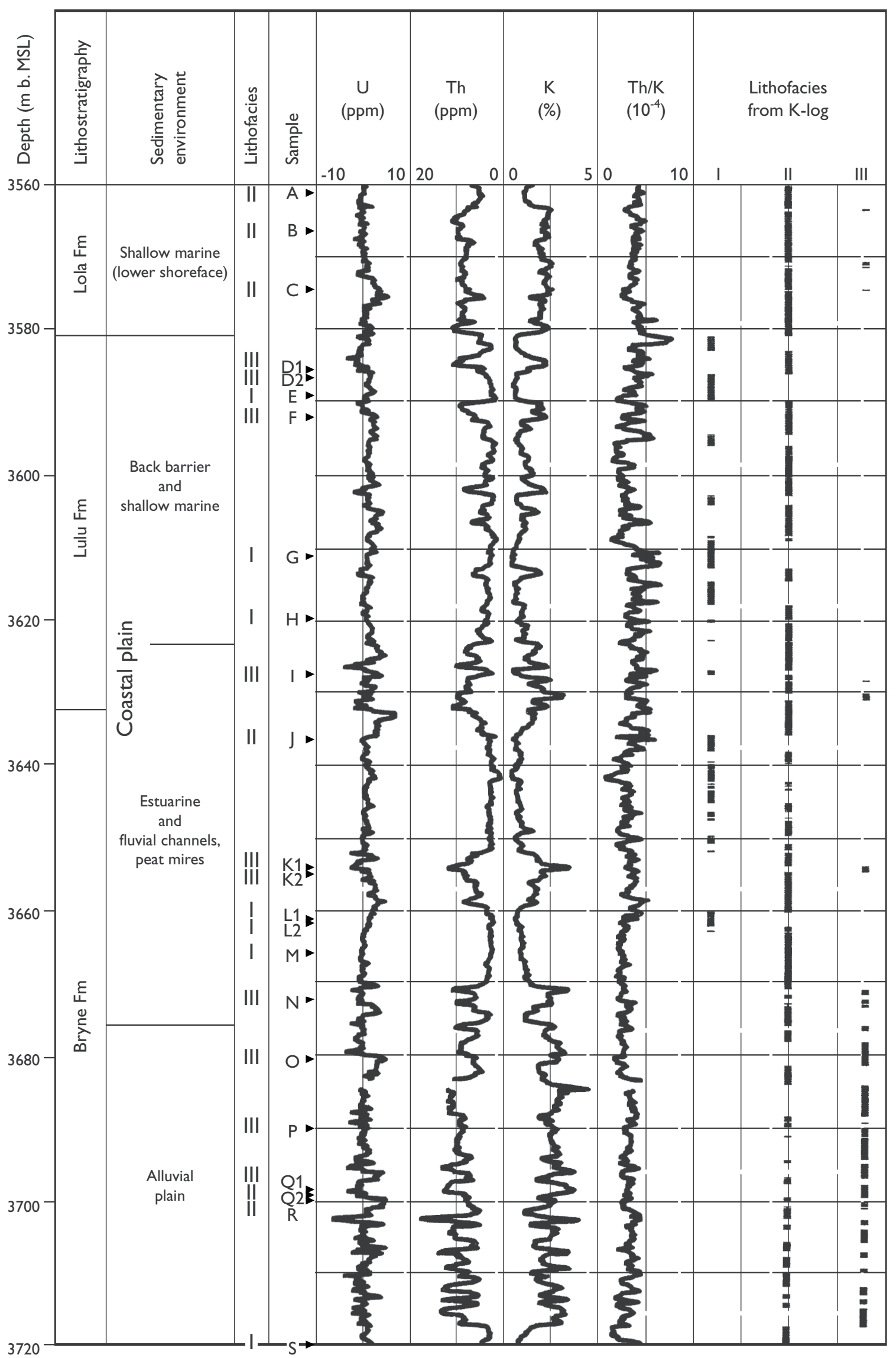


tically insoluble and is thus commonly concentrated in residual deposits such as bauxite and clay. Important quantities of thorium are found in the heavy minerals monazite, rutile and zircon. Zircon normally contains 100-2500 ppm Th (Nielsen et al. 1987), while monazite may contain substantially more.

Pure clay samples typically contain 5-30 ppm Th (Adams \& Weaver 1958). Theoretical considerations indicate that $\mathrm{Th}^{4+}$, with an ionic radius of $0.97 \mathrm{~nm}$, cannot be accommodated in the layer structure of clay minerals, so that Th in these minerals could be assumed to be fixed by adsorption (Adams \& Weaver 1958). Hurst \& Milodowski (1994) stated, however, that the origin of Th in clay minerals is unclear, and proposed that it is caused by inclusions of clay-sized heavy minerals. In the samples of Hassan et al. (1976), the Th content correlated with the content of clay minerals, but it was not proven that the clays were responsible for the Th enrichment.

\section{Uranium}

Under neutral $\mathrm{pH}$ conditions, the uranyl ion $\left((\mathrm{UO})^{2+}\right)$ forms ionic complexes with carbonates, which control its dispersion and mobility in nature. The uranyl ion also forms numerous complexes with organic compounds (e.g. humic acids), which facilitate its fixation by organic and mineral matter. Hassan et al. (1976) found that U shows a strong correlation with organic carbon, probably because $\mathrm{UO}_{2}$ precipitates under reducing conditions. Factors other than the content of organic matter (such as the availability of $\mathrm{U}$ ) may be important for the

\section{Facing page:}

Fig. 3. The natural spectral gamma-ray log over the cored interval of West Lulu-3. Samples investigated in the present study are indicated by the letters A-S. For the construction of the lithofacies $\log$, the $\mathrm{K}$ value from the spectral gamma borehole log was multiplied by 0.8 (as recommended in the text). Intervals in which the $\mathrm{K}$ content is $<0.7 \%$ are referred to lithofacies I, those with $0.7-2 \% \mathrm{~K}$ are referred to lithofacies II and the sediments with $>2 \% \mathrm{~K}$ are assigned to lithofacies III. The corresponding lithofacies of the core samples, as determined by laboratory measurements, are indicated by roman numerals. The sedimentary environment interpretations are by J. Andsbjerg (personal communication 1995; see also Andsbjerg 2003, this volume). occurrence of $\mathrm{U}$ in sediments as exemplified by the data of Berstad \& Dypvik (1982). In shales from the Cenozoic of the North Sea, these workers found no correlation between U and Total Organic Carbon (TOC). Uranium also occurs as a trace element in accessory minerals (zircon contains 300-3000 ppm U; Nielsen et al. 1987) and in colloidal Fe-oxide/hydroxide coatings on mineral grains. Uranium species may also be adsorbed onto clay minerals.

\section{Methods}

\section{Borehole gamma-ray measurement}

The SNG tool used for logging of the West Lulu-3 borehole uses five continuous energy windows covering the entire energy range from $0.1-3.0 \mathrm{MeV}$ (Fig. 4). The heart of the tool is a sodium iodide (NaI) crystal that detects the gamma rays in the borehole. A gamma-ray detector based on a NaI crystal is able to produce accurate data on the radioactivity in the surroundings. To interpret the spectrum correctly, however, it is necessary to take into account the influence of the drilling mud, variations in the borehole diameter and the standoff of the probe. The (net) uranium count rate in window W4 is usually low (Fig. 4), and the uranium measurements therefore become dependent on the count rates of the low-energy windows W1 and W2, which are influenced the most by the borehole parameters. This results in an unreliable U log curve. By using the whole spectrum, high count rates are attained, i.e. the statistical accuracy of the counting is high, but borehole correction factors must be included.

\section{Laboratory gamma-ray measurement}

Similar techniques can be used for laboratory measurements of gamma radiation from $\mathrm{K}$, Th and $\mathrm{U}$ in rock samples. Laboratory measurements were obtained with $\mathrm{NaI}$ crystals using three energy windows centred around the three most prominent gamma energy $\mathrm{K}$, Th and $\mathrm{U}$ peaks of the spectrum (Fig. 4). These measurements are in the high-energy part of the spectrum and thus less dependent on geometry, density and matrix influence. However, by using only counts from a fraction of the spectrum, longer counting times are needed.

For the present study, 19 core-sections (each c. 80 $\mathrm{cm}$ long) of the West Lulu-3 cores were selected on the basis of core inspection and the $\mathrm{K}$, Th and $\mathrm{U}$ signals of 


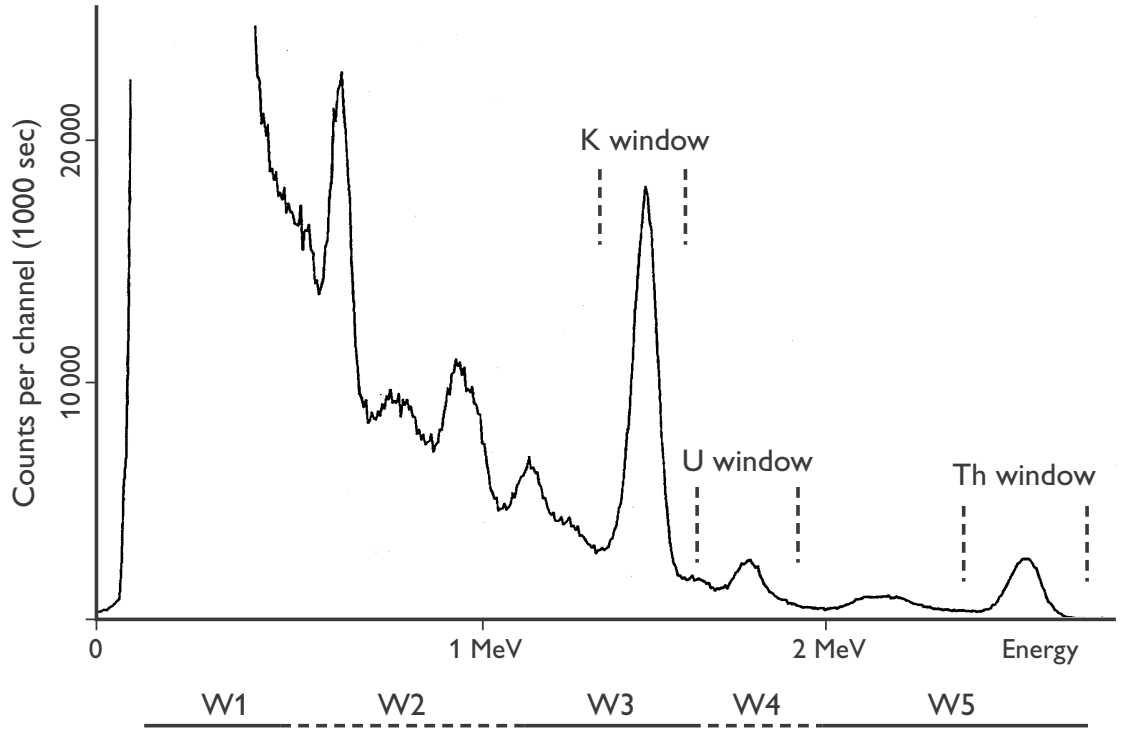

Fig. 4. Natural gamma-ray spectrum measured in the laboratory with a $\mathrm{NaI}$ crystal. Energy windows used for concentration determinations are centred around the three most prominent highenergy K, Th and U peaks. Natural gamma-ray spectra measured in boreholes contain the same peaks, but the spectra are blurred compared to a laboratory-measured spectrum, and the peaks are less distinct. The tool for the Natural Gamma Ray Spectrometry log in the West Lulu-3 well uses five continuous windows, W1-W5, covering the energy range from 0.1 to $3.0 \mathrm{MeV}$. At lower energies, the spectrum shape is significantly influenced by the borehole geometry and mud density. the SNG log. Ten of the sections are from the Bryne Formation, six are from the Lulu Formation and the upper three sections are from the lower levels of the Lola Formation (Figs 2, 3). The sections were chosen to cover the range of different $\mathrm{K}$, Th and $\mathrm{U}$ concentrations and ratios in the interval 11800-12 $300 \mathrm{ft}$ below Kelly Bushing, corresponding to $c$. 3560-3720 m below mean sea level. Each section was measured in the laboratory by a spectral natural gamma-ray scanner with a NaI crystal, and on the basis of these results, typical core intervals, $5-7 \mathrm{~cm}$ long, were selected from each core section for more detailed analysis. A total of 23 samples were collected. For each of these samples, the $\mathrm{K}$, Th and U contents were determined by a Ge(Li) gamma spectrometer. Most samples were selected from intervals with stable $\mathrm{K}$, Th and $\mathrm{U}$ readings.

\section{Mineralogy and chemistry}

After removal of a reference slab, samples were taken for the preparation of thin sections and polished specimens. The thin sections were described by optical microscopy, and the polished specimens were used for back-scatter electron microscopy (BSEM) and energydispersive microprobe analysis (EDS).

For each selected interval, a sample of $c .125 \mathrm{~g}$ was cut out, crushed and homogenised. Measurement of TOC, inorganic carbon and sulphur was undertaken on $0.5 \mathrm{~g}$ size sub-samples after ignition in a LECO CS 225 furnace. The K, Th and $\mathrm{U}$ content of the crushed samples was measured by placing the samples inside a laboratory
NaI crystal gamma spectrometer. By this method, low levels of radioactivity can be measured. Approximately $120 \mathrm{~g}$ of each sample were subsequently separated into grain-size fractions by wet and dry sieving.

The mineral content of the clay size $(<2 \mu \mathrm{m})$, fine silt size $(2-20 \mu \mathrm{m})$, coarse silt - very fine sand (20-125 $\mu \mathrm{m})$, and coarser sand fractions (125-250 $\mu \mathrm{m}, 250-600$ $\mu \mathrm{m}$ and $>600 \mu \mathrm{m})$ was determined by X-ray diffractometry (XRD) using Ni-filtered $\mathrm{Cu}-\mathrm{K} \alpha$ radiation at apparatus settings of $40 \mathrm{kV}$ and $40 \mathrm{~mA}$ with the step scanning variant slit. The effectiveness of the grain-size separation and the mineralogy of the fractions was checked by microscopy. On the basis of these data, the separated fractions for each sample were remixed into three portions: clay $(<2 \mu \mathrm{m})$, silt and very fine sand $(2-125$ $\mu \mathrm{m})$ and coarser sand $(>125 \mu \mathrm{m})$. These three portions were chosen because within each portion, only minor differences in mineralogy were observed. For each of the three portions, the K, Th and U concentrations were determined by gamma-ray spectrometry.

Separation of the samples into fractions of individual minerals was not attempted, but the mineralogical composition of the samples was estimated, and the contribution from each mineral to the total $\mathrm{K}$ was inferred in the following way. The amount of organic matter in each sample was assumed to be equal to the TOC. The amount of carbonate was calculated from inorganic carbon with reference to XRD data. All sulphur was assumed to be associated with pyrite unless barite was detected, in which case optical microscope and XRD data formed the basis for partitioning the sulphur between barite and pyrite. The amounts of K-feldspar, 
Table 1. Geochemical data, mineralogy and interpreted mineral contribution to $\mathrm{K}$ content

\begin{tabular}{|c|c|c|c|c|c|c|c|c|c|c|c|c|c|c|c|c|c|c|c|c|c|c|}
\hline \multirow[b]{2}{*}{ Sample* } & \multirow[b]{2}{*}{$\begin{array}{l}\text { Depth } \\
\text { metre } \\
\text { b. MSL }\end{array}$} & \multirow[b]{2}{*}{$\begin{array}{l}\text { Litho- } \\
\text { facies }\end{array}$} & \multicolumn{3}{|c|}{$\begin{array}{l}\text { Geochemical data } \\
\text { (wt\%) }\end{array}$} & \multicolumn{12}{|c|}{$\begin{array}{c}\text { Interpreted mineral content } \\
\text { (\%; based on XRD, BSEM and petrography) }\end{array}$} & \multicolumn{5}{|c|}{$\begin{array}{l}\text { Interpreted contribution to } \\
\qquad \mathrm{K} \text { content }(\%)\end{array}$} \\
\hline & & & 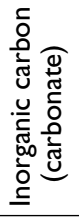 & 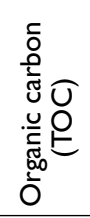 & 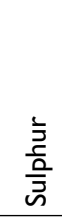 & 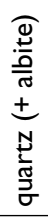 & $\begin{array}{l}\frac{1}{\pi} \\
\frac{0}{0} \\
\frac{0}{0} \\
\frac{1}{1}\end{array}$ & 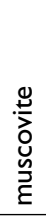 & 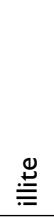 & $\begin{array}{l}\stackrel{\Xi}{\Xi} \\
\stackrel{. \Xi}{0} \\
\stackrel{\Xi}{\Xi}\end{array}$ & 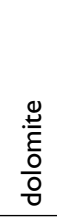 & 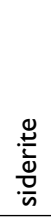 & 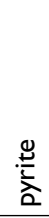 & ర్ర & م. & 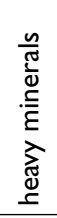 & 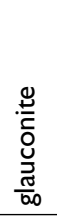 & $\begin{array}{l}\stackrel{\Xi}{\Xi} \\
\stackrel{\underline{\Xi}}{0} \\
\stackrel{\Xi}{\Xi} \\
\end{array}$ & 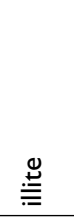 & 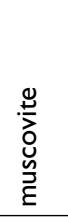 & $\begin{array}{l}\frac{1}{\pi} \\
\frac{0}{0} \\
\frac{0}{0}\end{array}$ & 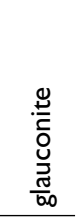 \\
\hline $\mathrm{H}$ & 3619.4 & I & 0.09 & 0.26 & 0.4 & 93 & 1 & 1 & - & 1 & 1 & - & - & - & 3 & - & - & 0.03 & 0.0 & 0.1 & 0.15 & - \\
\hline$E$ & 3588.5 & I & 0.14 & 2.47 & 0.1 & 87 & 1 & - & 1 & 5 & 1 & - & 1 & 3 & - & 1 & - & 0.15 & 0.07 & 0.0 & 0.15 & - \\
\hline G & 3610.4 & I & 0.03 & 0.64 & 0.1 & 89 & 1 & - & 1 & 5 & - & - & - & - & 1 & 3 & - & 0.15 & 0.07 & 0.0 & 0.15 & - \\
\hline$M$ & 3665.2 & I & 0.13 & 0.13 & 0.3 & 93 & 3 & 1 & - & 1 & 1 & - & 1 & - & - & - & - & 0.03 & 0.0 & 0.07 & 0.4 & - \\
\hline $\mathrm{J}$ & 3635.6 & II & 0.04 & 3.18 & 0.0 & 81 & 1 & - & 1 & 13 & - & - & - & 3 & - & 1 & - & 0.4 & 0.07 & 0.0 & 0.15 & - \\
\hline L1 & 3660.7 & I & 0.08 & 0.25 & 0.2 & 88 & 2 & 1 & - & 7 & 1 & - & - & - & 1 & - & - & 0.2 & 0.0 & 0.1 & 0.3 & - \\
\hline L2 & 3661.0 & I & 0.13 & 0.19 & 0.1 & 88 & 2 & 1 & - & 7 & 1 & - & - & - & 1 & - & - & 0.2 & 0.0 & 0.1 & 0.3 & - \\
\hline$S$ & 3720.1 & 1 & 0.38 & 0.08 & 0.0 & 88 & 2 & 1 & 3 & 3 & 3 & - & - & - & - & - & - & 0.03 & 0.15 & 0.1 & 0.3 & - \\
\hline$A$ & 3561.2 & II & 1.40 & 0.67 & 0.5 & 73 & 3 & 2 & 2 & 5 & 11 & - & 1 & 1 & - & - & 2 & 0.01 & 0.14 & 0.2 & 0.44 & 0.07 \\
\hline Q2 & 3698.7 & II & 0.03 & 0.19 & 0.0 & 77 & 2 & 3 & 9 & 9 & - & - & - & - & - & - & - & 0.09 & 0.5 & 0.3 & 0.3 & - \\
\hline $\mathrm{K} 2$ & 3654.2 & III & 0.04 & 1.88 & 0.1 & 68 & - & - & 6 & 24 & - & - & - & 2 & - & - & - & 0.7 & 0.4 & 0.0 & 0.0 & - \\
\hline $\mathrm{R}$ & 3700.0 & II & 0.05 & 8.23 & 0.2 & 59 & 2 & 1 & 15 & 15 & - & - & - & 8 & - & - & - & 0.15 & 0.8 & 0.1 & 0.3 & - \\
\hline B & 3566.3 & II & 0.01 & 2.18 & 1.0 & 60 & 3 & 4 & 9 & 18 & - & - & 2 & 2 & - & - & 2 & 0.04 & 0.7 & 0.4 & 0.44 & 0.07 \\
\hline$C$ & 3573.9 & II & 0.10 & 2.20 & 0.9 & 60 & 3 & 4 & 9 & 18 & 1 & - & 2 & 2 & - & - & 1 & 0.04 & 0.7 & 0.4 & 0.44 & 0.018 \\
\hline D2 & 3585.9 & III & 0.31 & 10.25 & 0.1 & 38 & - & 1 & 16 & 33 & 2 & - & - & 10 & - & - & - & 1.0 & 1.1 & 0.1 & 0.0 & - \\
\hline $\mathrm{F}$ & 3591.6 & III & 0.03 & 2.84 & 0.1 & 41 & 1 & - & 10 & 45 & - & - & - & 3 & - & - & - & 1.4 & 0.7 & 0.0 & 0.15 & - \\
\hline D1 & 3585.5 & III & 0.05 & 8.28 & 0.2 & 43 & - & 4 & 15 & 30 & - & - & - & 8 & - & - & - & 0.9 & 1.1 & 0.4 & 0.0 & - \\
\hline 1 & 3627.0 & III & 0.00 & 5.00 & 0.1 & 32 & - & 1 & 6 & 56 & - & - & - & 5 & - & - & - & 1.7 & 0.4 & 0.1 & 0.0 & - \\
\hline Q1 & 3698.0 & III & 0.32 & 0.12 & 0.0 & 44 & 1 & 2 & 25 & 25 & 3 & - & - & - & - & - & - & 0.3 & 1.3 & 0.2 & 0.15 & - \\
\hline$P$ & 3689.7 & III & 2.70 & 0.93 & 0.0 & 25 & 1 & 1 & 31 & 16 & 2 & 23 & - & 1 & - & - & - & 0.16 & 2.2 & 0.1 & 0.15 & - \\
\hline K1 & 3653.8 & III & 0.10 & 1.10 & 0.1 & 28 & - & - & 14 & 56 & 1 & - & - & 1 & - & - & - & 1.7 & 1.0 & 0.0 & 0.0 & - \\
\hline$N$ & 3671.0 & III & 0.30 & 0.80 & 0.0 & 36 & 1 & 7 & 35 & 18 & 2 & - & - & 1 & - & - & - & 0.18 & 2.5 & 0.7 & 0.15 & - \\
\hline 0 & 3680.7 & III & 0.02 & 0.51 & 0.0 & 27 & 1 & 2 & 45 & 23 & 1 & - & - & 1 & - & - & - & 0.3 & 3.2 & 0.2 & 0.15 & - \\
\hline
\end{tabular}

* Samples listed in order of increasing $\mathrm{K}$ content (bulk sample), see Table 3.

clay minerals and mica were calculated from the gamma spectrometry and EDS potassium measurements, guided by the semi-quantitative XRD and microscope data on mineral abundance. On the basis of these data and EDS analysis of the $\mathrm{K}$ content in the observed minerals, the contribution from each mineral to the total $\mathrm{K}$ was calculated. The presence and identity of heavy minerals were determined by microscopy and EDS analysis.

\section{Results}

\section{Facies analysis}

On the basis of thin-section microscopy, the samples were classified into lithofacies I, II and III; a similar classification was developed by Vernik \& Nur (1992; Table 1).
Lithofacies I (five samples) comprises well-sorted quartz arenites with a maximum clay content of $2-3 \%$. The samples are from sedimentary rocks that are primarily interpreted to represent channel-fill sediments within paralic and coastal plain/floodplain environments (Fig. 3; Johannessen \& Andsbjerg 1993; Andsbjerg 2003 , this volume). Porosity is in the range $23-28 \%$, and permeability is in the range $200-2000 \mathrm{mD}$.

Lithofacies II (eight samples) consists of grain-supported quartz arenites with up to $18 \%$ clay. The samples are from sedimentary rocks interpreted to represent coastal plain/floodplain and lower shoreface environments of deposition (Fig. 3; Johannessen \& Andsbjerg 1993; Andsbjerg 2003, this volume). Porosity is in the range $11-17 \%$ and permeability is in the range $0.4-25 \mathrm{mD}$.

Lithofacies III (ten samples) comprises wackes and sandy shales (matrix-supported, with occasional grainto-grain contacts) containing more than 18\% clay. The 

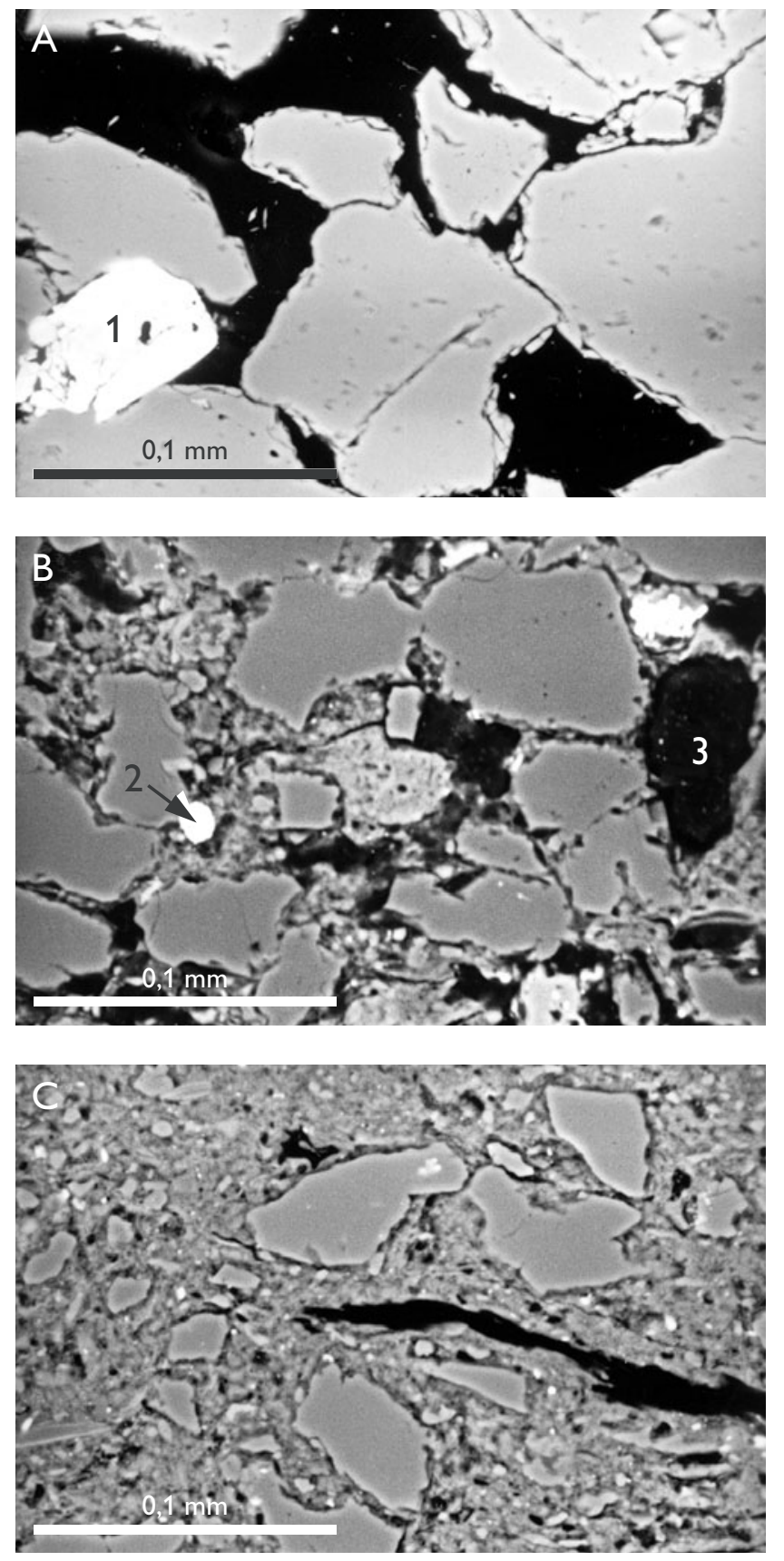

Fig. 5. Back-scatter electron microscope images. A: Lithofacies I, core sample E. Porous, grain-supported quartz arenite with isolated heavy mineral grains, such as zircon (1). B: Lithofacies II, core sample C. Grain-supported quartz wacke, with no visible porosity. Grains include: $\mathbf{2}$, pyrite; $\mathbf{3}$, glauconite. C: Lithofacies III, core sample K2. Matrix-supported quartz wacke.

sampled facies are interpreted, in the main, to represent a coastal plain/floodplain environment of deposition (Fig. 3; Johannessen \& Andsbjerg 1993; Andsbjerg 2003, this volume). Porosity is less than or equal to $11 \%$, and
Table 2. Grain-size fractions of crushed samples

\begin{tabular}{|c|c|c|c|c|c|}
\hline Sample ${ }^{\ddagger}$ & Lithofacies & $\begin{array}{c}(>125 \mu \mathrm{m}) \\
(\%)\end{array}$ & $\begin{array}{c}(2-125 \mu \mathrm{m}) \\
(\%)\end{array}$ & $\begin{array}{c}(<2 \mu \mathrm{m}) \\
(\%)\end{array}$ & $\begin{array}{c}\text { Total } \\
\text { (\%) }\end{array}$ \\
\hline $\mathrm{H}$ & I & 77.99 & 17.63 & 3.18 & 98.8 \\
\hline $\mathrm{E}$ & I & 49.08 & 46.41 & 3.04 & 98.53 \\
\hline G & I & 69.02 & 24.44 & 2.84 & 96.3 \\
\hline$M$ & I & 58.2 & 37.64 & 2.71 & 98.55 \\
\hline$J$ & II & 45.19 & 46.52 & 6.76 & 98.47 \\
\hline L1 & I & 64.07 & 31.08 & 3.94 & 99.09 \\
\hline L2 & I & 62.11 & 32.39 & 6.47 & 100.97 \\
\hline$S$ & I & 74.05 & 21.57 & 3.85 & 99.47 \\
\hline A & II & 0.6 & 89.67 & 6.78 & 97.05 \\
\hline Q2* & II & - & 25.97 & 13.95 & - \\
\hline $\mathrm{K} 2 *$ & III & 9.8 & 70.37 & 18.54 & 98.71 \\
\hline $\mathrm{R}^{*}$ & II & 7.51 & 81.96 & 7.3 & 96.77 \\
\hline $\mathrm{B}^{*}$ & II & 3.07 & 83.48 & 8.61 & 95.16 \\
\hline$C^{*}$ & II & 4.24 & 82.82 & 10.49 & 97.54 \\
\hline $\mathrm{D} 2 *$ & III & 24.22 & 63.8 & 7.45 & 95.47 \\
\hline $\mathrm{F}^{*}$ & III & 23.79 & 58.95 & 15.72 & 98.46 \\
\hline D1* & III & 23.69 & 66.38 & 6.8 & 96.87 \\
\hline |* & III & 21.68 & 62.86 & 11.32 & 95.86 \\
\hline Q1* & III & 10 & 73.92 & 17.4 & 101.32 \\
\hline $\mathrm{P}^{*}$ & III & 31.28 & 54.7 & 10.05 & 96.03 \\
\hline $\mathrm{K} 1 *$ & III & 28.89 & 52.31 & 13.71 & 94.91 \\
\hline $\mathrm{N}^{*}$ & III & 14.12 & 67.84 & 9.6 & 91.56 \\
\hline O* & III & 16.62 & 65.62 & 17.26 & 99.5 \\
\hline
\end{tabular}

*The silt and sand fractions contain lumps of non-disaggregated material.

¥ Samples listed in order of increasing K content (bulk sample), see Table 3.

permeability below $0.5 \mathrm{mD}$. Characteristic BSEM images of each lithofacies are presented on Figure 5.

Crushing and grain size separation were successful for samples of lithofacies I, and some of lithofacies II, but not for samples of lithofacies III and several lithofacies II samples, where the coarser fractions contain mineral aggregates. Although the fine fractions may include pieces broken from the coarser grains during sample crushing, no such pieces were observed. The sieve data are presented in Table 2 .

\section{Mineralogy}

Quartz is present in all samples as sand- and silt-sized grains. Samples of lithofacies I contain sand-size quartz grains with diameters greater than $130 \mu \mathrm{m}$, samples of lithofacies II have quartz grains of very fine sand and coarse silt size (50-130 $\mu \mathrm{m})$, and samples of lithofacies III, as a rule, contain only silt-size particles. One sample of lithofacies III though, contains quartz grains as 

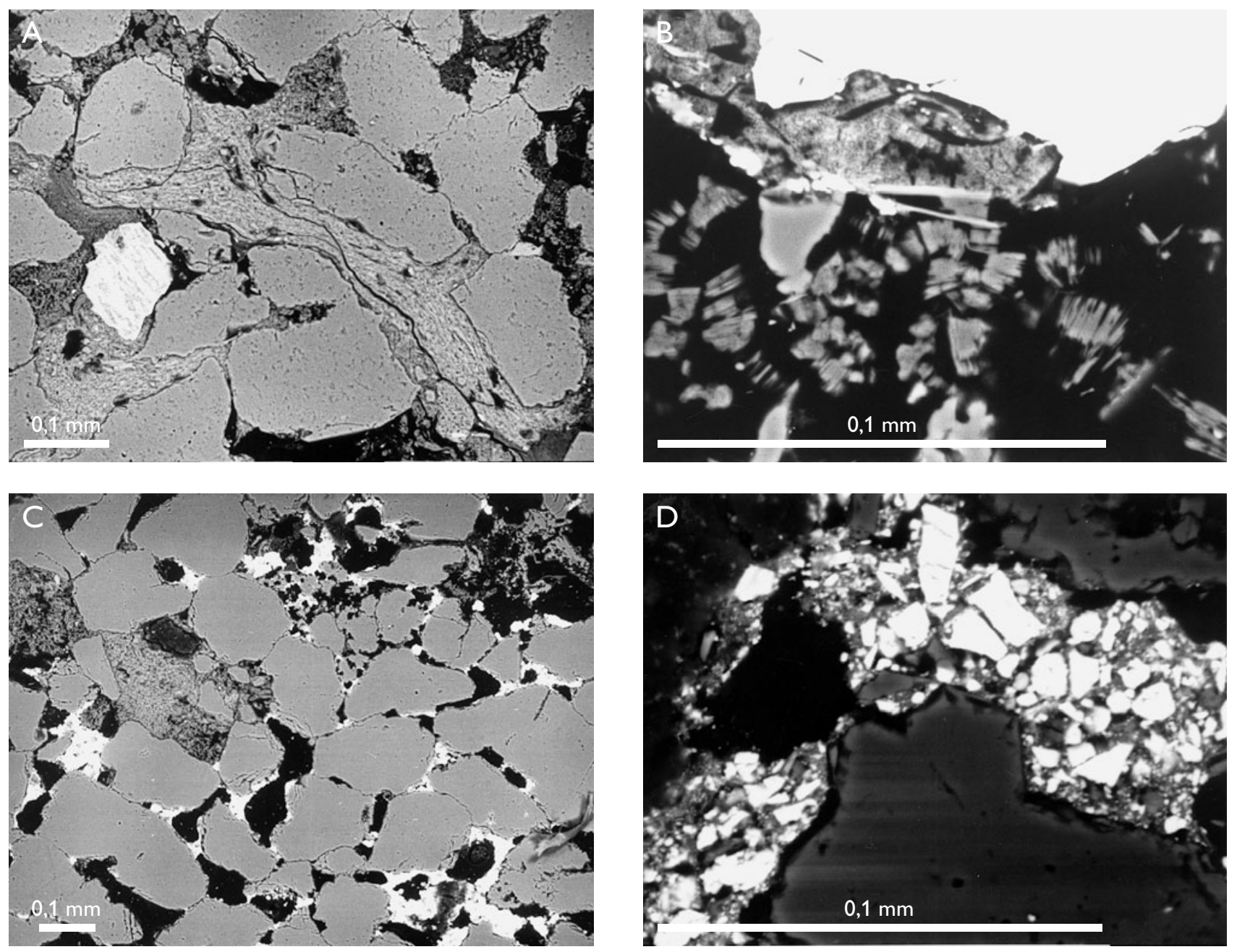

Fig. 6. Back-scatter electron microscope images. A: Allochthonous clay (illite and kaolinite) between sand grains in sandstone of lithofacies II; core sample J. B: Authigenic kaolinite platelets in sandstone of lithofacies I. The bright grain in the upper part of the picture is rutile; core sample M. C: Particles of barite (white) caught in the pore space of a lithofacies I sandstone, due to drilling mud invasion; core sample H. D: The fabric observed in C, at higher magnification, showing the characteristic textural habit of barite.

large as $80 \mu \mathrm{m}$. Some diagenetic quartz overgrowths are seen in samples of lithofacies I and II.

Feldspar. K-feldspar grains have been detected in 18 of the 23 samples from a combination of XRD, thin-section study and EDS. In 16 of the samples, grains of plagioclase and K-feldspar have been found, and in four samples only plagioclase was found. The only type of plagioclase detected by EDS is albite. The content of plagioclase barely exceeds a few percent by volume in any sample, and no quantification was attempted. The estimated quartz content (Table 1) therefore probably includes a minor component of plagioclase. Both degraded and fresh feldspars are observed in lithofacies III samples, whereas feldspar grains in lithofacies I and II samples are generally degraded. No indications of preferential degradation of either plagioclase or K-feldspar was noted.

Muscovite was found in most samples (Table 1). The textural relationships indicate that the muscovite is of detrital origin. It is generally fresh and unaltered. EDS analysis indicated a K content close to the ideal (10\%).

Illite is present in the clay fraction of most samples, with the exception of some from lithofacies I (Table 1). EDS analysis indicated that the illites of samples A-P contain around 7\% K and the illites of samples Q-S contain $5 \% \mathrm{~K}$. Illite was found in clay of apparently detrital origin (Fig. 6A). 
Table 3. Gamma-spectral analysis of bulk sample

\begin{tabular}{|c|c|c|c|c|}
\hline Sample* & Lithofacies & K (\%) & Th (ppm) & U (ppm) \\
\hline $\mathrm{H}$ & I & $0.25 \pm 0.01$ & $1.0 \pm 0.4$ & $0.4 \pm 0.1$ \\
\hline$E$ & I & $0.42 \pm 0.02$ & $8.2 \pm 0.5$ & $3.2 \pm 0.1$ \\
\hline G & I & $0.47 \pm 0.02$ & $3.8 \pm 0.4$ & $1.5 \pm 0.1$ \\
\hline$M$ & I & $0.57 \pm 0.01$ & $2.7 \pm 0.4$ & $1.1 \pm 0.1$ \\
\hline$J$ & II & $0.59 \pm 0.01$ & $1.8 \pm 0.4$ & $0.3 \pm 0.1$ \\
\hline L1 & I & $0.60 \pm 0.02$ & $2.6 \pm 0.6$ & $0.5 \pm 0.1$ \\
\hline L2 & I & $0.60 \pm 0.02$ & $5.5 \pm 0.4$ & $0.9 \pm 0.1$ \\
\hline $\mathrm{S}$ & I & $0.67 \pm 0.02$ & $1.0 \pm 0.4$ & $0.1 \pm 0.1$ \\
\hline$A$ & II & $0.87 \pm 0.02$ & $3.9 \pm 0.5$ & $1.2 \pm 0.1$ \\
\hline Q2 & II & $1.18 \pm 0.02$ & $5.7 \pm 0.5$ & $1.2 \pm 0.1$ \\
\hline $\mathrm{K} 2$ & III & $1.21 \pm 0.03$ & $10.7 \pm 0.6$ & $3.9 \pm 0.1$ \\
\hline $\mathrm{R}$ & ॥ & $1.92 \pm 0.03$ & $8.0 \pm 0.6$ & $2.6 \pm 0.1$ \\
\hline B & II & $1.99 \pm 0.03$ & $8.0 \pm 0.6$ & $2.8 \pm 0.1$ \\
\hline $\mathrm{C}$ & ॥ & $2.00 \pm 0.03$ & $11.6 \pm 0.6$ & $3.2 \pm 0.1$ \\
\hline D2 & III & $2.05 \pm 0.04$ & $13.3 \pm 0.7$ & $4.0 \pm 0.2$ \\
\hline $\mathrm{F}$ & III & $2.15 \pm 0.03$ & $13.2 \pm 0.6$ & $4.0 \pm 0.1$ \\
\hline D1 & III & $2.17 \pm 0.02$ & $10.2 \pm 0.5$ & $3.4 \pm 0.1$ \\
\hline 1 & III & $2.17 \pm 0.03$ & $11.1 \pm 0.7$ & $3.3 \pm 0.1$ \\
\hline Q1 & III & $2.37 \pm 0.03$ & $10.3 \pm 0.6$ & $2.5 \pm 0.1$ \\
\hline$P$ & III & $2.42 \pm 0.03$ & $7.3 \pm 0.5$ & $2.7 \pm 0.1$ \\
\hline K1 & III & $2.89 \pm 0.03$ & $12.3 \pm 0.6$ & $2.7 \pm 0.1$ \\
\hline$N$ & III & $3.30 \pm 0.03$ & $16.2 \pm 0.6$ & $3.6 \pm 0.1$ \\
\hline O & III & $3.51 \pm 0.03$ & $16.9 \pm 0.6$ & $3.2 \pm 0.1$ \\
\hline
\end{tabular}

Sample size: $18 \mathrm{~cm}^{3}$.

Uncertainties are one standard deviation.

*Samples listed in order of increasing K content (bulk sample).

Kaolinite was detected in all samples, being the dominant mineral in several samples of lithofacies III. Authigenic kaolinite as well as detrital kaolinite were observed (Fig. 6). No attempt was made to differentiate between different polytypes. The measured K content of the kaolinites (by EDS) in the present samples have the following general pattern: samples $\mathrm{A}-\mathrm{C}$, around $0.1 \% \mathrm{~K}$; samples D-M, approximately 3\% K; samples $\mathrm{N}-\mathrm{S}$, approximately $1 \% \mathrm{~K}$.

Heavy minerals. Grains of zircon, rutile and chromite were identified by optical microscopy and EDS. They occur in significant amounts in sample $\mathrm{E}$ and $\mathrm{G}$ of lithofacies I, and in sample J of lithofacies II.

Pyrite is present in most of the samples where it is commonly associated with organic matter (Fig. 5).

Carbonate. Dolomitic cement was found in several samples (Table 1). In sample A, Fe-rich dolomite was identified with a $\mathrm{Mg} / \mathrm{Fe}$ (atomic) ratio of 1.4 (based on EDS). In sample P (lithofacies III), many siderite concretions, as well as dolomite, are present. The illite-rich sample $\mathrm{P}$ is from an interval that is interpreted to record an allu-
Table 4. Gamma-spectral analysis of clay fraction

\begin{tabular}{|c|c|c|c|c|}
\hline Sample* & Lithofacies & $\mathrm{K}(\%)$ & Th (ppm) & $\cup(p p m)$ \\
\hline $\mathrm{H}$ & I & $1.65 \pm 0.10$ & \pm 3 & $2.4 \pm 0.6$ \\
\hline$E$ & I & $1.80 \pm 0.14$ & \pm 4 & $1.7 \pm 0.8$ \\
\hline G & I & $2.28 \pm 0.13$ & \pm 3 & $1.9 \pm 0.8$ \\
\hline$M$ & I & $2.81 \pm 0.15$ & $15 \pm 4$ & $3.5 \pm 0.9$ \\
\hline$J$ & II & $2.36 \pm 0.07$ & $8.7 \pm 1.5$ & $2.7 \pm 0.3$ \\
\hline L1 & I & $2.50 \pm 0.10$ & $15 \pm 3$ & $2.1 \pm 0.6$ \\
\hline L2 & I & $2.02 \pm 0.07$ & $10.9 \pm 1.7$ & $1.5 \pm 0.4$ \\
\hline $\mathrm{S}$ & I & $2.98 \pm 0.12$ & $12 \pm 3$ & $1.6 \pm 0.7$ \\
\hline$A$ & II & $3.50 \pm 0.11$ & $18 \pm 2$ & $1.6 \pm 0.5$ \\
\hline Q2 & II & $2.88 \pm 0.05$ & $10.1 \pm 1.1$ & $2.1 \pm 0.3$ \\
\hline $\mathrm{K} 2$ & III & $1.63 \pm 0.05$ & $12.3 \pm 1.1$ & $3.6 \pm 0.2$ \\
\hline $\mathrm{R}$ & II & $4.05 \pm 0.07$ & $19.0 \pm 1.4$ & $5.9 \pm 0.3$ \\
\hline B & II & $2.98 \pm 0.08$ & $13.8 \pm 1.7$ & $3.5 \pm 0.4$ \\
\hline $\mathrm{C}$ & II & $3.54 \pm 0.05$ & $15.2 \pm 1.0$ & $4.1 \pm 0.2$ \\
\hline D2 & III & $2.14 \pm 0.06$ & $10.9 \pm 1.4$ & $2.4 \pm 0.3$ \\
\hline $\mathrm{F}$ & III & $2.41 \pm 0.05$ & $14.2 \pm 1.0$ & $3.8 \pm 0.2$ \\
\hline D1 & III & $2.64 \pm 0.06$ & $12.0 \pm 1.4$ & $4.7 \pm 0.3$ \\
\hline I & III & $2.42 \pm 0.05$ & $13.1 \pm 1.0$ & $3.0 \pm 0.2$ \\
\hline Q1 & III & $3.41 \pm 0.05$ & $12.0 \pm 0.1$ & $2.1 \pm 0.2$ \\
\hline$P$ & III & $4.17 \pm 0.08$ & $18.5 \pm 1.6$ & $3.1 \pm 0.4$ \\
\hline K1 & III & $3.36 \pm 0.07$ & $15.7 \pm 1.3$ & $3.9 \pm 0.3$ \\
\hline$N$ & III & $4.35 \pm 0.06$ & $16.5 \pm 1.2$ & $2.4 \pm 0.3$ \\
\hline O & III & $4.29 \pm 0.05$ & $16.2 \pm 0.9$ & $2.7 \pm 0.2$ \\
\hline
\end{tabular}

Uncertainties are one standard deviation.

*Samples listed in order of increasing K content (bulk sample), see Table 3.

vial plain setting (Fig. 3; Andsbjerg 2003, this volume). This concurs with the common observation of siderite in anoxic freshwater deposits (Postma 1983).

Barite is present in minor amounts, as indicated by the XRD pattern of four samples of lithofacies I (Table 1). Barite was only found in the clay and silt fractions. BSEM imaging reveals the textural habit of the barite, showing that the barite content is the result of infiltration of fine-grained particles from the drilling mud into permeable lithofacies I sandstones (Fig. 6C, D).

Glauconite was found in the three samples (A-C) from the Lola Formation. This is thought to concur with the interpreted environment of deposition (lower shoreface). A potassium content of $2-4 \mathrm{wt} \%$ was measured by EDS.

\section{Gamma-spectral analysis}

The results of the gamma-spectral analysis of the crushed samples are listed in Table 3. The results from gammaspectral analysis of the clay fractions are given in 

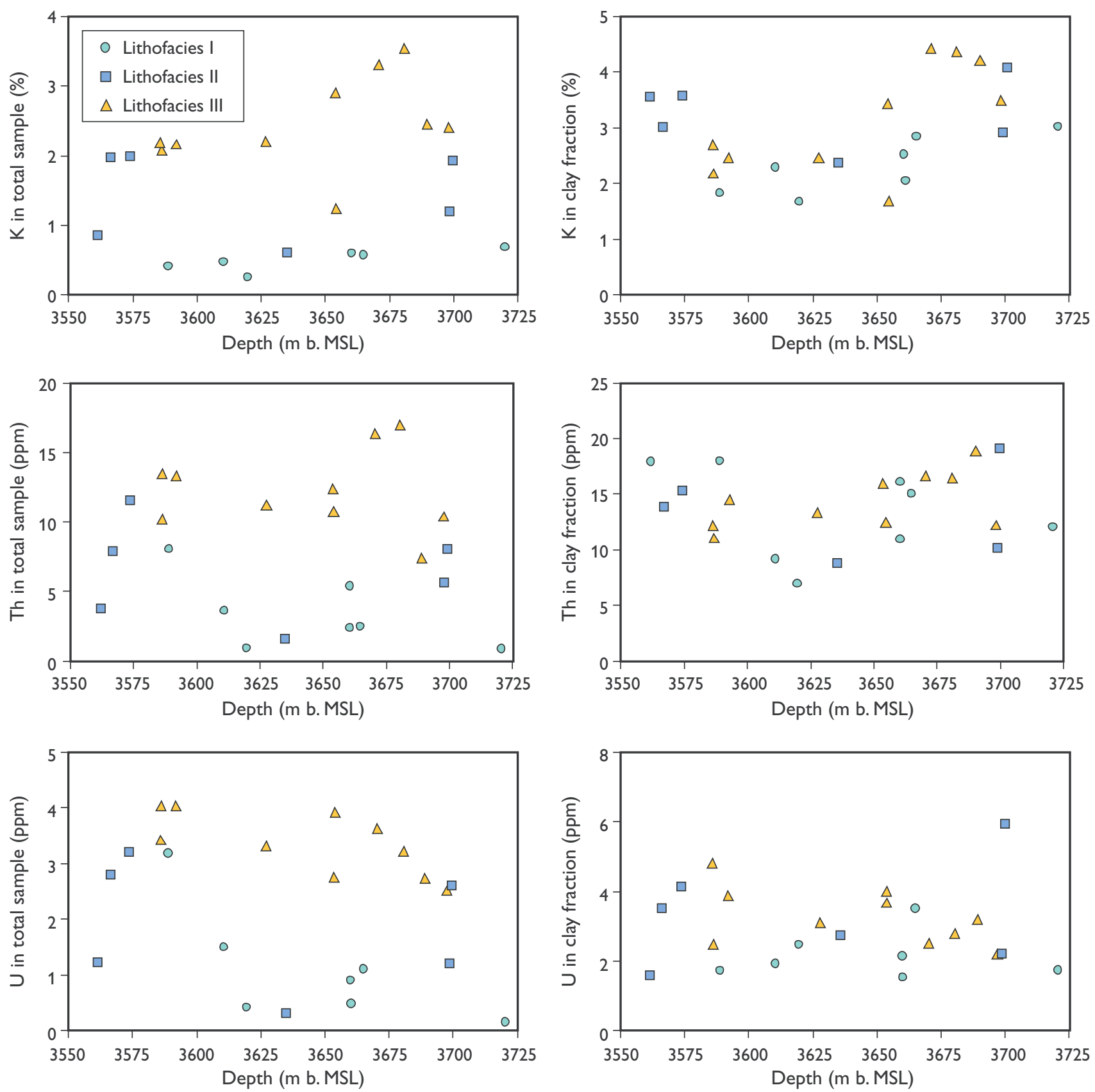

Fig. 7. Content of K, Th and U in total crushed samples and in clay fractions versus sample depth. Samples of lithofacies I contain less than $0.7 \% \mathrm{~K}$, whereas the Th and $\mathrm{U}$ values are variable, dependent on a varying content of heavy minerals. Samples of lithofacies II have $0.6-2 \% \mathrm{~K}$, and variable contents of Th and U. Samples of lithofacies III generally have more than $2 \% \mathrm{~K}$, more than 7 ppm Th and more than $2.5 \mathrm{ppm}$ U. The clay fraction data indicate a stratigraphic variation in K content, decreasing slightly with depth down to $3650 \mathrm{~m}$ followed by a broad increase between 3650 and $3725 \mathrm{~m}$. The Th content tends to follow the same pattern as K. Similar variations are not apparent for $\mathrm{U}$.

Table 4. The data for the coarser fractions are not listed. These fractions do not represent the values for the 'true' grain size interval because of the incomplete disaggregation of the original sample. The interpreted total mineralogy of the samples, and the interpreted contribution from each mineral to the total K content of each sample, are listed in Table 1.

Potassium concentrations are low in lithofacies I samples $(<0.7 \%)$, higher in lithofacies II samples (0.6-2\%), and highest in lithofacies III (generally $>2 \%$ although 


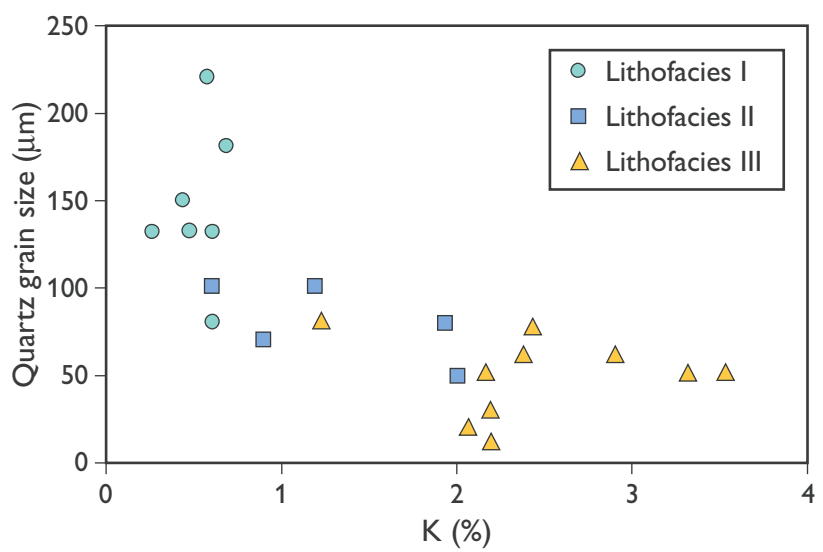

Fig. 8. Median size of quartz grains, estimated from thin sections, vs. K content. Samples of lithofacies I contain less than $0.7 \% \mathrm{~K}$ and comprises quartz grains in the range 130-220 $\mu \mathrm{m}$. Samples of lithofacies II contain $0.6-2 \% \mathrm{~K}$ and consist of quartz grains in the range $50-130 \mu \mathrm{m}$. Samples of lithofacies III generally contain more than $2 \% \mathrm{~K}$ and are made up of quartz grains less than $80 \mu \mathrm{m}$ in size.

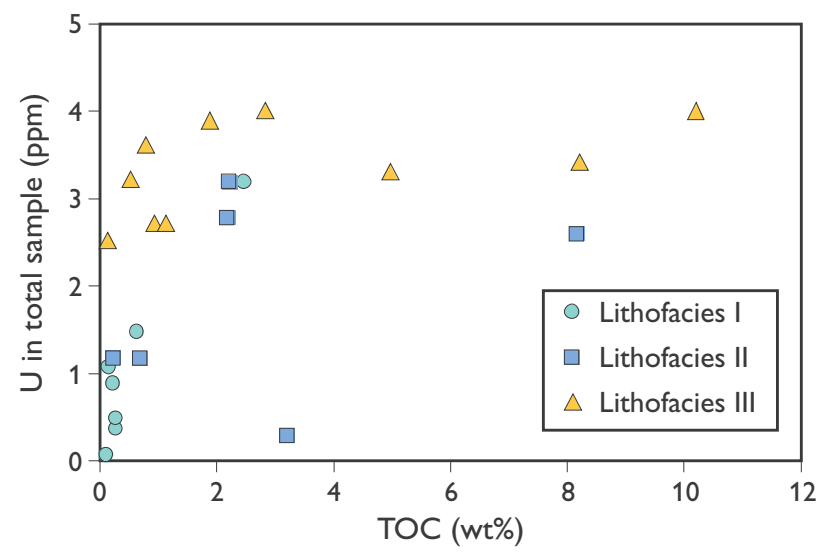

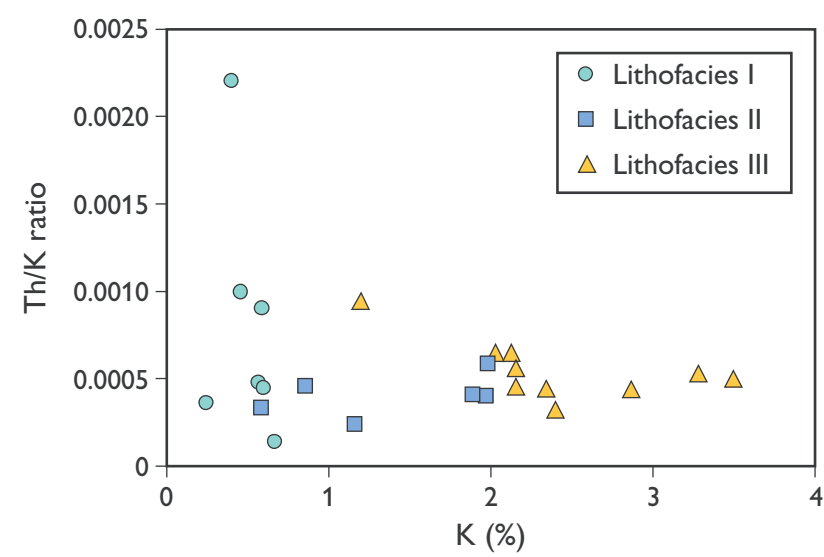

Fig. 9. Th/K ratio vs. K content. The $\mathrm{Th} / \mathrm{K}$ ratio does not effectively separate the lithofacies I, II and III, although lithofacies I samples rich in heavy minerals can be differentiated by their high $\mathrm{Th} / \mathrm{K}$ ratio.

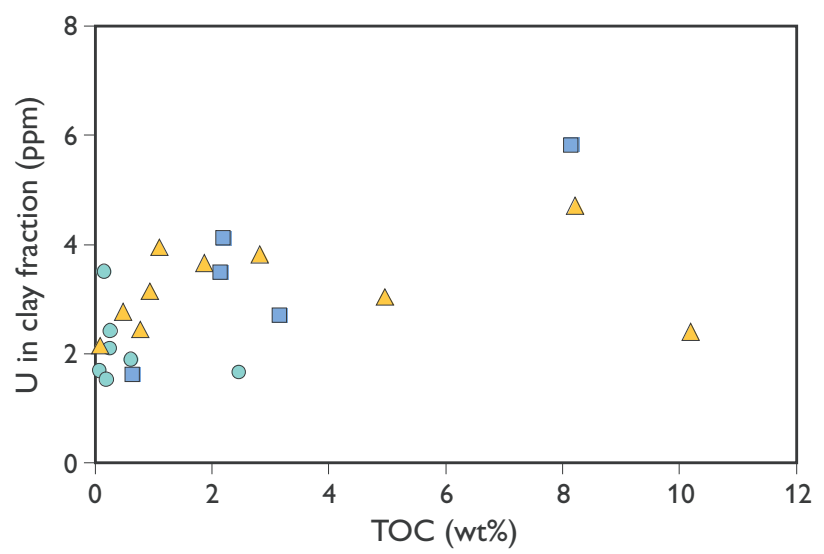

Fig. 10. U concentrations in the total samples and in the clay fractions vs. TOC. No general relationship between U and TOC is apparent from the two figures. Total samples of lithofacies I are low in TOC and show a large variation in U, samples of lithofacies II show a scattered pattern, while samples of lithofacies III give constant high U values and a large variation in TOC.

one sample contains $1.2 \% \mathrm{~K}$; Figs 7 , 8). This differentiation of lithofacies in terms of $\mathrm{K}$ content was not observed for the clay fraction. Considering all the data, the $\mathrm{K}$ content of the clay component shows a weak decrease with increasing depth to around $3650 \mathrm{~m}$; at greater depths, the data show considerable scatter but appear to broadly increase between 3650 and $3725 \mathrm{~m}$ (Fig. 7). The Th and U concentrations of the total samples are variable in lithofacies I and II, but uniformly high in lithofacies III (Fig. 7). The Th content in the clay fraction follows roughly the same pattern as the K content (see above), while no pattern is apparent for the $\mathrm{U}$ content of the clay fraction (Fig. 7). For lithofacies II and III samples, roughly constant $\mathrm{Th} / \mathrm{K}$ ratios of $3 \times 10^{-4}$
$10 \times 10^{-4}$ were obtained, whereas lithofacies I samples show significant variation in this ratio $\left(2 \times 10^{-4}-22 \times\right.$ $10^{-4}$; Fig. 9). This is a consequence of lithofacies I samples being low in $\mathrm{K}$ but having variable Th and $\mathrm{U}$ contents; it is assumed that this variability is governed by the heterogenereous distribution of heavy minerals within the facies.

\section{Total Organic Carbon (TOC)}

Fragments of organic matter are found in most samples of lithofacies II and III and in a single sample of lithofacies I. A general negative relationship between car- 

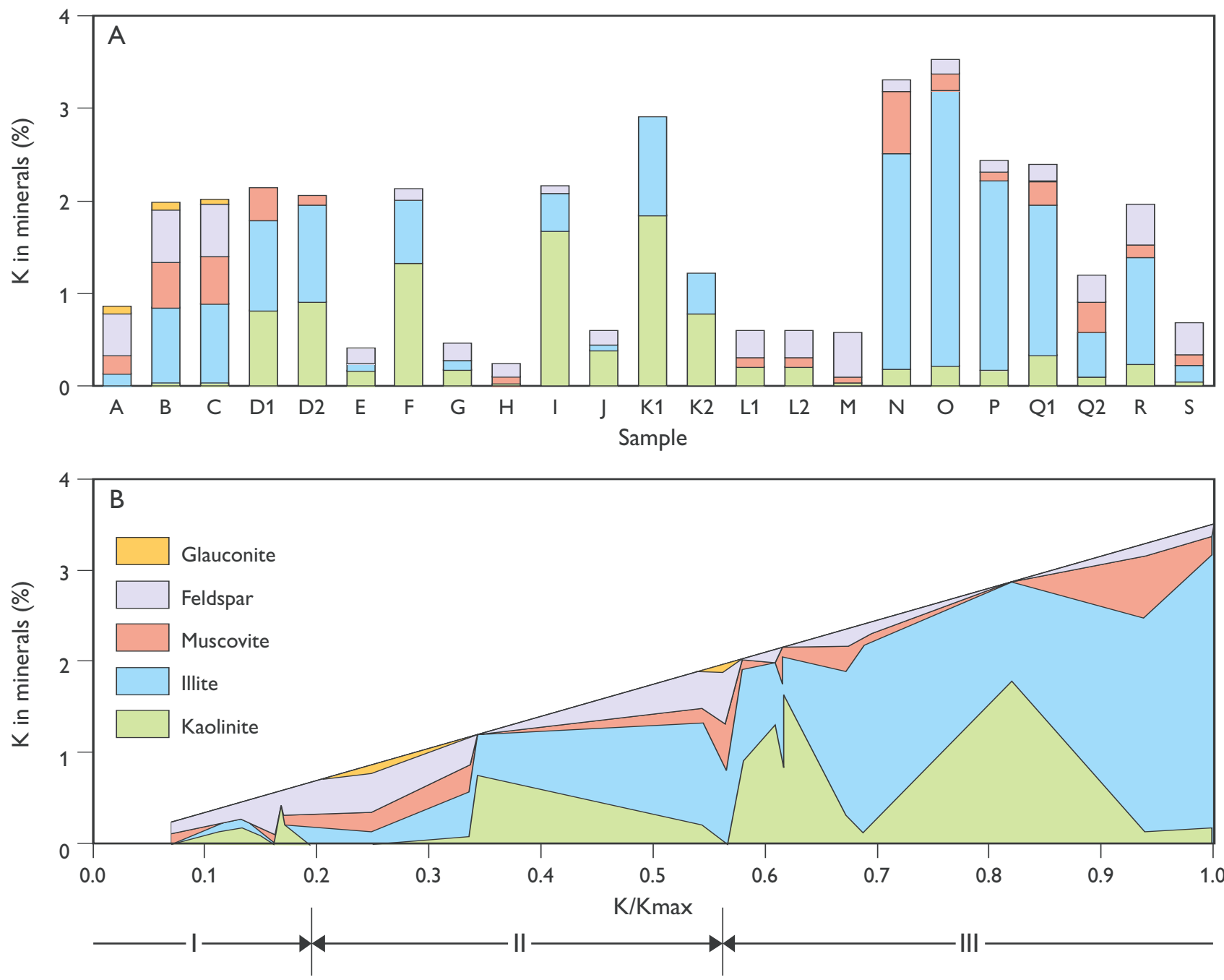

Fig. 11. The cumulative contributions of the K-bearing minerals to the total K concentration, both for individual samples (A) and ranked in progressive $\mathrm{K}$ content (B). Glauconite is only present in the samples from the Lola Formation (above $3575 \mathrm{~m}$, i.e. samples A-C), while illite gains drastically in importance relative to kaolinite below $3665 \mathrm{~m}$ (samples N-S). In samples of lithofacies I, K-feldspar is the dominant source of potassium; in samples of lithofacies II, K-feldspar, muscovite and illite dominate; in samples of lithofacies III, illite and partly illitised kaolinite are the major sources of potassium.

bonate and TOC can be noticed (Table 1). Samples of lithofacies I give low TOC values but show a large variation in U content (Fig. 10). Samples of lithofacies II display a large variation in both TOC and U, while lithofacies III samples have a high content of $U$ and a large TOC variation. Uranium concentration and TOC are apparently independent.

\section{Location of potassium}

The data suggest that feldspar is the main source of $\mathrm{K}$ in the K-poor lithofacies I sandstones, while mica and kaolinite are a minor source (Fig. 11). The intermedi- ate $\mathrm{K}$ content of lithofacies II sandstones is probably primarily due to feldspar, mica and illite, while kaolinite contributes less. In the K-rich lithofacies III samples, feldspar is of only minor importance, whereas illite and kaolinite are inferred to have roughly equal importance as a source of $\mathrm{K}$.

In Figure 11, inferred contributions to the total $\mathrm{K}$ from the minerals in each sample are presented in order of depth. The low K values measured by EDS in kaolinites from below $3660 \mathrm{~m}$ (i.e. samples L1-S) are responsible for the low contribution to the total $\mathrm{K}$ attributed to kaolinite below this depth. 


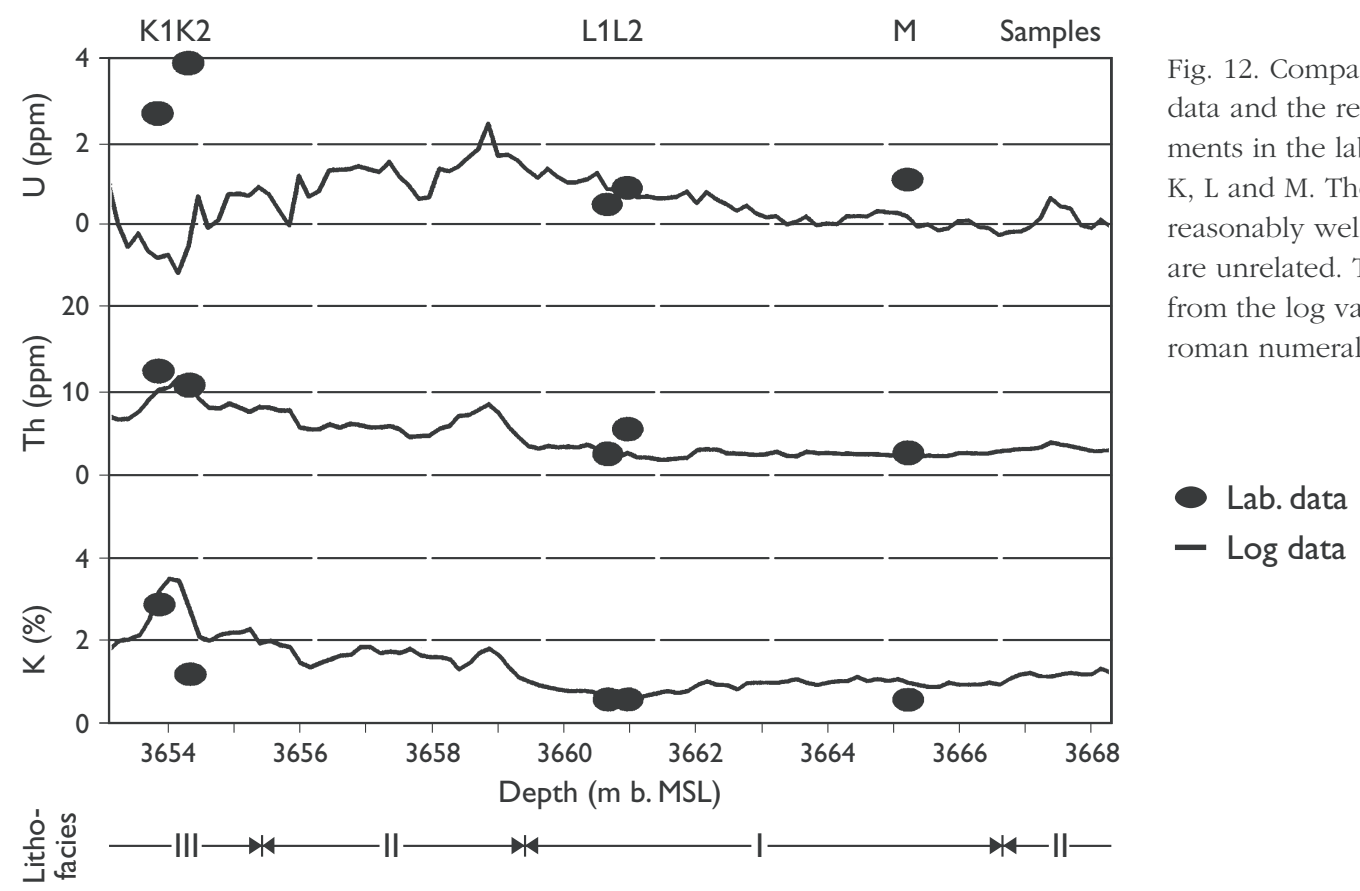

\section{Laboratory gamma spectrometry of cores vs. log data}

Comparison between the SNG log data and the results from the measurements of the gamma radiation in the laboratory reveals significant differences (Fig. 12). On average, the laboratory data indicate $20 \%$ lower K concentrations than the log data. For Th, the laboratory results are on average 5\% lower than the log values. Interpretation of the $\mathrm{U}$ data is complicated; the log shows negative concentrations in some intervals, and no correlation was found between log data and laboratory measurements. This concurs with the findings of Hurst (1990) who also observed that U values from the SNG log in North Sea boreholes were unreliable.

\section{Discussion}

\section{Diagenetic factors}

The coexistence of kaolinite and feldspar in sandstones has been the subject of much discussion in the literature (Lindgreen 1985; Bjørkum \& Gjelsvik 1988; Aja et al. 1991; Bjørkum et al. 1993). At temperatures higher than $50-80^{\circ} \mathrm{C}$ (or according to Bjørlykke \& Egeberg (1993), above $90-100^{\circ} \mathrm{C}$ ), kaolinite and $\mathrm{K}$-feldspar may react to form authigenic illite and quartz cement. The extensive illitisation of sandstones of the Garn Formation, offshore Norway, is interpreted to have arisen because the sandstone reached either a temperature of $140^{\circ} \mathrm{C}$ or a time-temperature index (TTI) of 100 (Ehrenberg 1990; see Waples 1980 for an introduction to the TTI maturity index). A temperature near the critical value of $140^{\circ} \mathrm{C}$ was recorded during logging of the studied reservoir interval of West Lulu-3. Quartz cement is frequently observed, and some detrital kaolinite contains up to $3 \% \mathrm{~K}$, while no $\mathrm{K}$ was detected in the authigenic kaolinite. An explanation for the varying degree of illitisation of kaolinite can be a difference in polytype between the detrital and authigenic kaolinite. Ehrenberg et al. (1993) described replacement of kaolinite by dickite in three sandstone formations on the Norwegian continental shelf. Apparently, the transformation from kaolinite to dickite takes place at temperatures above $120-130^{\circ} \mathrm{C}$ via dissolution/re-precipitation. Ehrenberg et al. (1993) found more extensive illitisation of kaolinite than of dickite, possibly because this process is kinetically favoured over illitisation of dickite.

The presence of carbonate and kaolinite cements is thought to reflect the release of acid pore waters from shales. Milliken \& Land (1991) related the acid pore waters to illitisation of smectite, whereas Curtis (1983) and Hansley \& Nuccio (1992) attributed the acid pore water to the maturation of kerogen. The acid pore water destabilises carbonate and aluminosilicates in the shales, $\mathrm{CO}_{2}$ and metal ions go into solution, and sediment compaction forces some of these modified pore waters into sandstones. If the sandstones contain reactive feldspar (i.e. detrital metamorphic or magmatic feldspars), acids 
from the shales are effectively buffered, thus allowing precipitation of carbonate and/or kaolinite. Curtis (1983) concluded that once the supply of reactive detrital feldspar is exhausted through dissolution and albitisation, shale-derived hydrogen ions remobilise carbonate in sandstones, generating secondary porosity and fluids with high $p \mathrm{CO}_{2}$. No secondary porosity was recognized in thin sections of the West Lulu-3 samples, and in line with the interpretation of Curtis (1983), feldspar is present in practically all samples.

\section{Lithofacies identification based on gamma spectrometry}

As demonstrated by Figures 7 and 8, the samples from the three lithofacies are most effectively separated on the basis of the K content. Thus grain-supported porous (clay-poor) quartz arenites (lithofacies I) contain $<0.7 \%$ $\mathrm{K}$, grain-supported, clay-rich quartz arenites (lithofacies II) contain $0.6-2 \% \mathrm{~K}$ whereas the matrix-supported wackes of lithofacies III contain $>2 \% \mathrm{~K}$. In Figure 3, the distribution of these three lithofacies is presented, calculated on the basis of (corrected) log data. Lithofacies II occurs throughout the section but particularly dominates the uppermost interval where it is interpreted to represent a lower shoreface sedimentary environment (J. Andsbjerg, personal communication 1995). Lithofacies I, showing good reservoir properties, is common in the upper part of the Bryne Formation and in the Lulu Formation where it typically occurs within channel-fill sections of paralic (estuarine) origin (J. Andsbjerg, personal communication 1995; Andsbjerg 2003, this volume). The clay-dominated lithofacies III is mainly found in the lower part of the studied section which is interpreted to represent an alluvial plain sedimentary environment (J. Andsbjerg, personal communication 1995; Andsbjerg 2003, this volume).

Schlumberger (1982) reported how the NSG tool can differentiate between different types of sandstone. Feldspathic sandstones or arkoses will typically have $\mathrm{Th} / \mathrm{K}$ ratios less than $1 \times 10^{-4}$, because of their low Th and their high $\mathrm{K}$ contents whereas micaceous sandstones have a $\mathrm{Th} / \mathrm{K}$ ratio close to $2.5 \times 10^{-4}$ because of the presence of Th-bearing heavy minerals. The $\mathrm{Th} / \mathrm{K}$ ratios in claybearing sandstones are still higher. This is consistent with the present clay-bearing samples (lithofacies II and III) which have $\mathrm{Th} / \mathrm{K}$ ratios of $3 \times 10^{-4}-10 \times 10^{-4}$. By contrast, this ratio varies widely in the lithofacies I samples (Th/K: $\left.2 \times 10^{-4}-22 \times 10^{-4}\right)$, depending on the feldspar and heavy mineral content. Thus, high $\mathrm{Th} / \mathrm{K}$ ratios can be found in mineralogically mature lithofacies I sandstones. The lithofacies as defined in this study are expected to reflect the reservoir quality of the rock, but they cannot be predicted from the $\mathrm{Th} / \mathrm{K}$ ratio. Hurst (1990) also found $\mathrm{Th} / \mathrm{K}$ cross-plots to be poorly suited to identifying and quantifying the clay mineralogy of sandstones.

\section{Potassium content of minerals}

As noted above, feldspar is inferred to be the main source of $\mathrm{K}$ in lithofacies I and II samples, whereas illite and kaolinite are the dominant sources of $\mathrm{K}$ in lithofacies III samples. The K-feldspars of lithofacies I and II samples commonly appear degraded, but a K content of $c .14 \%$ is typical. The illite has a highly variable $\mathrm{K}$ content, whereas the larger mica grains (muscovite) have a K content close to the ideal (10\%). Some kaolinite grains (mainly diagenetic) are free of $\mathrm{K}$, while others (probably detrital) have a $\mathrm{K}$ content of about 3\%. In the samples from the shallow marine Lola Formation, glauconite contributes to the $\mathrm{K}$ content. The $\mathrm{K}$ content of the glauconite was measured to be $2-4 \%$ by EDS.

The K content of the clay fraction of the samples shows no apparent relationship with lithofacies, but shows broad variation with depth, as described earlier. This could be explained by a change in clay mineralogy due to diagenesis (see above), as some indications of transformation of kaolinite into illite were noted. This explanation, however, is contradicted by two observations: (1) the pattern does not show a uniform depthrelated trend and (2) several of the deepest samples are rich in kaolinite relative to illite. The best explanation for the broad variations with depth is probably stratigraphic variations in the provenance of the clastic material.

\section{Sources of uranium and thorium}

Hassan et al. (1976) and Schlumberger (1982) have reported that uranium commonly shows a strong correlation with organic carbon. In common with the data of Berstad \& Dypvik (1982), this study has demonstrated no such correlation. Imam \& Trewin (1991) stated that in the sandstones of the Claymore Sandstone Member of the Kimmeridge Clay Formation, the contribution to radioactivity from organic matter is minor, while the high gamma-ray radiation is considered to be due to high K-feldspar concentrations and radioactive heavy minerals, particularly zircon and monazite. Our data support their conclusions. 


\section{Comparison of log and laboratory data}

The observed discrepancy between log and laboratory measurements could be due to calibration problems, differences in measuring geometry or due to the influence of the drilling mud.

\section{Calibration}

One may assume that both borehole tool and laboratory equipment are in this case calibrated correctly. The laboratory equipment for measurements of samples is regularly checked using reference material from the International Atomic Energy Agency in Vienna (IAEA 1987). The core scanner is checked using secondary reference material. According to standard practice, the SNG tool is calibrated regularly.

\section{Measuring geometry}

The individual samples investigated in the laboratory are much smaller than the volume contributing to the measurements of the borehole logging tool in the borehole. However, systematic variations such as those observed for $\mathrm{K}$ and Th cannot be explained in this way. Moreover, most samples were selected from intervals with stable concentrations of $\mathrm{Th}, \mathrm{U}$ and $\mathrm{K}$, so that this source of error is considered to be of minor importance. The crushed samples were measured in a fixed geometry (in a laboratory NaI crystal detector), and the core slices of different thickness were measured using reference material with similar geometries. The accuracy of the core scanner is dependent on core geometry (regular or fractured cores). For the cores investigated, such influence is minor and, in any event, for irregular cores the concentrations of $\mathrm{K}$, Th and $\mathrm{U}$ should be influenced to almost the same extent. The accuracy of borehole measurements is dependent on borehole geometry (variations in diameter). However, the associated caliper log indicates a fairly constant borehole diameter.

\section{Borehole mud}

Borehole measurements are influenced by the density and chemistry of the drilling mud. No major potassium-, thorium-, or uranium-bearing additives (e.g. $\mathrm{KCl}$ ) were present in the mud. Major amounts of barite were added in order to achieve a mud density of $1.9 \mathrm{~g} / \mathrm{cm}^{3}$. Barite attenuates gamma-rays entering the borehole from the formation, especially in the lower part of the energy spectrum. If this influence is not properly taken into account, low or even negative $U$ concentrations may result from the calculations. From data reported by Ellis (1982), calculated Th concentrations may be expected to be higher than the real concentrations under conditions of high barite content.

Normally, a correction for high density borehole mud is included in the calculations by the logging company, but that apparently was not the case for the West Lulu-3 $\log$. The problem is not trivial because it is impossible to perform recalculations without detailed information on the correction program. By multiplying the log concentrations of Th and $\mathrm{K}$ by 0.95 and 0.80 respectively, values approximately similar to those measured in the laboratory can be obtained. Unfortunately the log concentrations of $\mathrm{U}$ cannot be transformed to comply with the laboratory values by any simple procedure.

\section{Conclusions}

1. From optical microscopy, X-ray diffraction and EDS microprobe data, we infer that the main sources of potassium are feldspar, muscovite, illite and illitised kaolinite. K-feldspar is the main source in samples with a limited amount of clay, while illite and illitised kaolinite are most important in the clay-rich intervals.

2. Neither gamma-spectral K nor Th was found to be a measure of clay content, but the $\mathrm{K}$ concentration provides a method of recognising the three broad lithofacies adopted here. Porous quartz arenites have $\mathrm{K}$ concentrations below $0.7 \%$, grain-supported quartz arenities with pore-filling clay have $\mathrm{K}$ concentrations between 0.6 and $2 \%$, while matrix-supported wackes normally have $\mathrm{K}$ concentrations above $2 \%$. It is possible, therefore, to define the lithofacies on the basis of the K signal of the Spectral Natural Gamma log.

3. The $\mathrm{K}$ content of the clay fraction varies as a function of depth, independent of sandstone texture. This is probably the result of changes in clay provenance.

4. The $\mathrm{Th} / \mathrm{K}$ ratio does not give an indication of the lithofacies in this study. Clay-bearing samples (those of lithofacies II and III) have Th/K ratios of $3 \times 10^{-4}$ $10 \times 10^{-4}$, whereas in the lithofacies I samples this 
ratio varies widely (Th/K: $\left.2 \times 10^{-4}-22 \times 10^{-4}\right)$ depending on the content of feldspar and heavy minerals.

5. Thorium and uranium signals are primarily indicative of the presence of heavy minerals in the sediments. No correlation was found between the U content and the total organic carbon content.

6. The volume of individual samples investigated in the laboratory is much smaller than the volume 'seen' by the SNG logging tool in the borehole. However, most samples were selected from intervals with stable concentrations of Th, $\mathrm{U}$ and $\mathrm{K}$, so that the samples are inferred to be representative for the depth intervals from which they were taken. Therefore, the geochemical results obtained in the laboratory can in general be compared directly to log data. Only few of the samples were taken from depth intervals with strongly varying concentrations of Th, $\mathrm{U}$ and $\mathrm{K}$.

7. A major discrepancy was observed between log data and laboratory gamma spectrometry data. Before interpreting the borehole log from West Lulu-3, the $\mathrm{K}$ concentrations should be multiplied by 0.8 , and the Th concentrations by 0.95 . The $\mathrm{U}$ concentrations cannot be corrected.

\section{Acknowledgements}

K. Carlsen, M. Christensen, V. Knudsen, H. Møller, S. Nguyen, A. Steffensen and I. Søndergaard are thanked for technical assistance. F. Larsen (Geological Survey of Denmark and Greenland), F. Engstrøm (Mærsk Olie og Gas AS) and S. Talman (Technical University of Denmark) are thanked for critically reading the manuscript. Special thanks are extended to the referees A. Hurst (University of Aberdeen) and J. Andsbjerg (Geological Survey of Denmark and Greenland) for valuable advice.

\section{References}

Adams, J.A.S. \& Weaver, C.E. 1958: Thorium-to-Uranium ratios as indicators of sedimentary processes: example of concept of geochemical facies. American Association of Petroleum Geologists Bulletin 42, 387-430.

Aja, S.U., Rosenberg, P.E. \& Kittrick, J.A. 1991: Illite equilibria in solutions: I. Phase relationships in the system $\mathrm{K}_{2} \mathrm{O}-\mathrm{Al}_{2} \mathrm{O}_{3}-\mathrm{SiO}_{2}-\mathrm{H}_{2} \mathrm{O}$. Geochimica et Cosmochimica Acta 55, 1353-1364.

Andsbjerg, J. 2003: Sedimentology and sequence stratigraphy of the Bryne and Lulu Formations, Middle Jurassic, northern
Danish Central Graben. In: Ineson, J.R. \& Surlyk, F. (eds): The Jurassic of Denmark and Greenland. Geological Survey of Denmark and Greenland Bulletin 1, 301-347 (this volume).

Berstad, S. \& Dypvik, H. 1982: Sedimentological evolution and natural radioactivity of Tertiary sediments from the central North Sea. Journal of Petroleum Geology 5, 77-88.

Bjørkum, P.A. \& Gjelsvik, N. 1988: An isochemical model for formation of authigenic kaolinite, K-feldspar and illite in sediments. Journal of Sedimentary Petrology 58, 506-511.

Bjørkum, P.A., Walderhaug, O. \& Aase, N.E. 1993: A model for the effect of illitization on porosity and quartz cementation of sandstones. Journal of Sedimentary Petrology 63, 1089-1091.

Bjørlykke, K. \& Egeberg, P.K. 1993: Quartz cementation in sedimentary basins. American Association of Petroleum Geologists Bulletin 77, 1538-1548.

Cowan, D.R. \& Myers, K.J. 1988: Surface gamma ray logs: a correlation tool for frontier areas: discussion. American Association of Petroleum Geologists Bulletin 72, 634-636.

Curtis, C.D. 1983: Link between aluminium mobility and destruction of secondary porosity. American Association of Petroleum Geologists Bulletin 67, 380-393.

Ehrenberg, S.N. 1990: Relationship between diagenesis and reservoir quality in sandstones of the Garn Formation, Haltenbanken, mid-Norwegian continental shelf. American Association of Petroleum Geologists Bulletin 74, 1538-1558.

Ehrenberg, S.N., Aagaard, P., Wilson, M.J., Fraser, A.R. \& Duthie, D.M.L. 1993: Depth-dependent transformation of kaolinite to dickite in sandstones of the Norwegian continental shelf. Clay Minerals 28, 325-352.

Ellis, D.V. 1982: Correction of NGT logs for the presence of KCl and barite muds. Society of Professional Well Log Analysts 23rd Annual Logging Symposium, July 6-9, 1982. Transactions, Paper O, 12 pp.

Engstrøm, F. 1981: Fortolkningsgrundlag for SNG-log, 469 pp. Unpublished Ph.D. thesis, Danmarks Tekniske Universitet, Lyngby, Danmark.

Hansley, P.L. \& Nuccio, V.F. 1992: Upper Cretaceous Shannon Sandstone reservoirs, Powder River Basin, Wyoming: evidence for organic acid diagenesis. American Association of Petroleum Geologists Bulletin 76, 781-791.

Hassan, M., Hossin, A. \& Combaz, A. 1976: Fundamentals of the differential gamma ray $\log$ - Interpretation technique. Society of Professional Well Log Analysts 17th Annual Logging Symposium, June 9-12, 1976. Transactions, Paper H, 18 pp.

Hurst, A. 1990: Natural gamma-ray spectroscopy in hydrocarbonbearing sandstones from the Norwegian continental shelf. In Hurst, A., Lovell, M.A., \& Morton, A.C. (eds): Geological Applications of Wireline Logs. Geological Society Special Publication (London) 48, 211-222.

Hurst, A. \& Milodowski, A. 1994: Characterisation of clays in sandstones: thorium content and spectral log data. Society of Professional Well Log Analysts 16th European Formation Evaluation Symposium, October 11-13, 1994. Transactions, Paper S, 18 pp.

IAEA 1987: Preparation and certification of IAEA gamma-ray spectrometry reference materials. Report file number IAEA/RL/148 Vienna: IAEA (International Atomic Energy Agency). 
Imam, M.B. \& Trewin, N.H. 1991: Factors contributing to high gamma-ray levels in Upper Jurassic sandstone reservoirs of the Claymore oilfield, North Sea. Marine and Petroleum Geology 8, $452-460$.

Johannessen, P.N. \& Andsbjerg, J. 1993: Middle to Late Jurassic basin evolution and sandstone reservoir distribution in the Danish Central Trough. In: Parker, J.R. (ed.): Petroleum geology of Northwest Europe: proceedings of the 4th conference, 271-283. London: Geological Society.

Lindgreen, H. 1985: Diagenesis and primary migration in Upper Jurassic claystone source rocks in North Sea. American Association of Petroleum Geologists Bulletin 69, 525-536.

Michelsen, O., Nielsen, L.H., Johannessen, P.N., Andsbjerg, J. \& Surlyk, F. 2003: Jurassic lithostratigraphy and stratigraphic development onshore and offshore Denmark. In: Ineson, J.R. \& Surlyk, F. (eds): The Jurassic of Denmark and Greenland. Geological Survey of Denmark and Greenland Bulletin 1, 147-216 (this volume).

Milliken, K.L. \& Land, L.S. 1991: Reverse weathering, the carbonate-feldspar system, and porosity evolution during burial of sandstones. American Association of Petroleum Geologists Bulletin 75, 636 only (abstract).

Nielsen, B.L., Løvborg, L., Sørensen, P. \& Mose, E. 1987: Gammaray analysis for $\mathrm{U}$, Th and $\mathrm{K}$ on bulk cutting samples from deep wells in the Danish Subbasin and the North German Basin, 82 pp. Unpublished report, Risø National Laboratory, Denmark.

Postma, D. 1983: Pyrite and siderite in brackish and freshwater swamp sediments. American Journal of Science 282, 1151-1183.

Schlumberger 1982: Natural gamma-ray spectrometry. Essentials of N.G.S. interpretation, 69 pp. Houston, Texas: Schlumberger Educational Services.

Vernik, L. \& Nur, A. 1992: Petrophysical classification of siliciclastics for lithology and porosity prediction from seismic velocities. American Association of Petroleum Geologists Bulletin 76, 1295-1309.

Waples, D.G. 1980: Time and temperature in petroleum formation: Application of Lopatin's method to petroleum exploration. American Association of Petroleum Geologists Bulletin 64, 916-926. 